Article

\title{
An Approach to Assessing Sustainability in the Development of a Manufacturing Company
}

\author{
Justyna Patalas-Maliszewska * (10) and Hanna Łosyk \\ Institute of Mechanical Engineering, University of Zielona Góra, 65-417 Zielona Góra, Poland; \\ H.Losyk@iim.uz.zgora.pl \\ * Correspondence: J.Patalas-Maliszewska@iim.uz.zgora.pl
}

Received: 27 August 2020; Accepted: 20 October 2020; Published: 22 October 2020

\begin{abstract}
In recent years, more reports and articles have been published on the necessity of implementing changes to manufacturing processes in the context of sustainable development (SD). The use of IT systems in manufacturing companies creates the opportunity to support changes implemented in the context of adaptation to the concept of SD. This paper proposes and explores a Sustainable Development Card (SDC) within an enterprise, the use of which will enable knowledge about the enterprise's development level to be gained in the context of SD through the data and information collected from the information system, namely, the Enterprise Resource Planning system (ERP) implemented within a company. This research uses studies from the literature on the subject and also the case study in order to determine the SDC integrated with the ERP system. The Analytic Hierarchy Process (AHP) method is used, which uses validity indicators to allow a manufacturing company's development to be evaluated within the context of SD. The results were verified by a real case study of a Polish manufacturing company. It was determined that the proposed approach allows SD to be assessed in a manufacturing company and enables the implementation process of SD strategy to be constantly monitored. This paper contributes to theory and practice at the interface of the development and sustainability of a manufacturing company, whereby assessing sustainability is associated with the development of strategy and information systems that are associated with the development of an organisation. The possibilities of using the results of research, in practice, are demonstrated convincingly.
\end{abstract}

Keywords: sustainable development; Enterprise Resource Planning (ERP); Analytic Hierarchy Process (AHP); manufacturing company

\section{Introduction}

The implementation and achievement of the goals of sustainable development (SD) in manufacturing enterprises consist in increasing productivity by minimising the consumption of resources and the emission of waste and by promoting the idea of reasonable and aware consumption, as well as protecting the natural environment [1]. It is assumed that the environment, society, and the economy constitute three commonly accepted areas of corporate SD [2-4].

SD in manufacturing is possible when the management of an enterprise has access to data and information, the analysis of which allows the level of development to be evaluated. IT systems enable enterprises to effectively manage resources through comprehensive and integrated solutions adjusted to the specificity of a given enterprise. An Enterprise Resource Planning (ERP) system can be treated as a kind of application that facilitates cooperation within a company [5]. An ERP system integrates all processes throughout the enterprise into one computer system [6]. For the purposes of this article, the specification of implementing and using an ERP system has been narrowed down to a group of 
manufacturing enterprises in the context of employing the functionality of the system with the aim of evaluating the level of SD in a given enterprise.

In the literature [7-10] the relationship between the development of strategy in a manufacturing company and sustainability has been discussed. The implementation of a sustainable development strategy within an enterprise enables the continuous monitoring and evaluation of activities carried out in order to achieve the goals of SD. The level of SD in an enterprise is usually measured with information and diagnostic tools that facilitate both the monitoring of the current condition, as well as management of the three spheres that are closely related to SD, namely, the social, economic, and environmental spheres. Information and diagnostic tools include indicators recommended for a system for monitoring sustainable development [11], among other indicators.

Given the central role played by achieving the objectives of SD within a manufacturing company through introducing and integrating sustainability into a development strategy, our research focusses on building the Sustainable Development Card (SDC). By this card, we mean the combination of SD objectives and indicators, along with data and information for receiving their values from the ERP system, implemented within an organisation, and the Analytic Hierarchy Process (AHP) method. The research question that we address is, therefore, 'How can sustainability in the development of a manufacturing company be assessed and integrated into the development strategy?' This new approach can be treated as a solution, which will direct—and help to monitor-a company's sustainable development based on real-time data and information, as updated and included in an ERP system.

This study investigates the determining factors that drive the assessment of sustainability through the use of the ERP system in a production company with the help of the AHP method. Therefore, an analytical framework was developed and applied in order to systematically analyse the sustainability indicators associated with the processes carried out and supported by the ERP system within a company.

So, the purpose of our paper is to build a model for evaluating the level of sustainable development in manufacturing for enterprises that have an ERP system in place, integrating into it the development of strategy. Our study thus makes three contributions to the theory and practice of assessing SD in manufacturing enterprises. First, our empirical study contributes to the validation and understanding of how the level of sustainable development in a company is measured, and how it can be continuously monitored and controlled as an integral part of a development strategy. Our study identifies the SD objectives and SD indicators and reference values for the SD indicators from the data of representative groups of manufacturing enterprise. The values of the SD indicators for an analysed company can be identified because of the ERP system implemented in a company. Because of the data and information from the ERP system, it is possible to integrate our proposed SDC into strategy development. Second, we extend the nascent literature in our approach to assessing sustainability in the development of a manufacturing company. Finally, as the result of an empirical case study, we contribute conceptually to the literature on assessing the development of sustainability in a manufacturing company by the use of the proposed SDC as an integral part of the development of strategy.

The second section presents the research literature in the field of sustainable development within manufacturing and the application of ERP systems as support for manufacturing enterprises in their implementation of SD objectives. It also carries out a critical analysis of currently known methods and tools for measuring the level of SD. The third section presents an approach to evaluating the level of sustainable development in manufacturing for enterprises that have an ERP system in place. Section 4 consists of a real case study of a Polish manufacturing company implementing the proposed model. Section 5 discusses the results obtained. Section 6 summarises the research and presents the benefits of applying the proposed solution to manufacturing enterprises.

\section{Literature Review}

Sustainable development is clearly becoming a moral as well as a legal responsibility. Society and organisations are encouraged to implement and abide by the five pillars of SD in order to fulfil current needs without decreasing future demand [9]: technical durability, economic balance, institutional 
balance, environmental balance, social balance. It is also stressed that organisational strategy and policy need to be formulated and applied in the entire process and in every decision-making aspect that affects SD [8]. SD also means that the company commits to optimising and harmonising its goals vis-à-vis multiple stakeholders $[12,13]$. A common approach to reach SD is the application of a technological solution in the form of new machinery and processes, which may require changes or corrections in decision-making with regards to process technology, organisational layout, workforce, production planning, and/or stock control [9]. According to Johansson and Winroth [14], SD in manufacturing strategy requires specific changes in many decision-making areas of an organisation. Small and Medium-Sized Enterprises (SME sector) is very often not fully integrated. The literature analysis was conducted on the relationship between the information systems used in companies, namely, the ERP system and sustainable development. Current studies [15-18] indicated a wide integration of sustainability elements into the ERP system (Table 1).

Table 1. Analysis of the literature on the relationship between the Enterprise Resource Planning (ERP) system and sustainable development (SD).

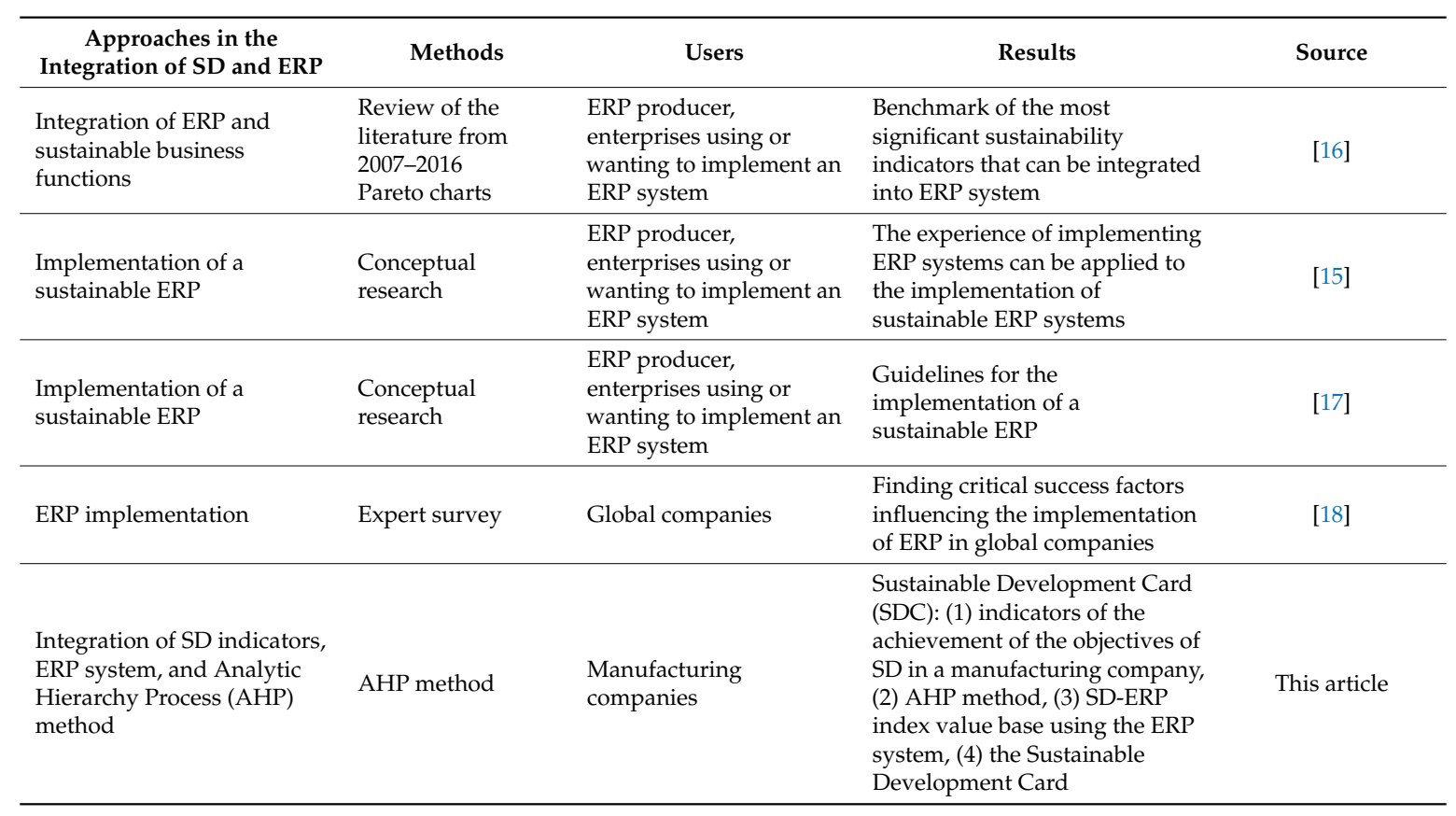

Based on the research analysis (Table 1) the research niche was observed in the context of a holistic approach for manufacturing companies by identifying the relationship between the ERP system and sustainable development. The approach presented combines the transfer of information on the results of SD objectives implementation and their impact in three aspects: economic, environmental, and social, using ERP system functionality in a given enterprise and the AHP method. The proposed approach will allow decisions to be supported when it comes to implementing the objectives and managing SD in manufacturing companies. This is particularly useful in improving the SD level within a manufacturing company. Having researched the source literature and measures applied in manufacturing companies, we formed an approach to assessing sustainability in the development of a manufacturing company. This consists of the following components: (1) indicators of the achievement of the objectives of SD in a manufacturing company, (2) the AHP method, (3) the SD-ERP index value base, using the ERP system, (4) the Sustainable Development Card. 


\section{Materials and Methods}

\subsection{Selection of Indicators for the Achievement of the Objectives of SD in a Manufacturing Company}

Developing indicators for the evaluation of sustainability is important as it is an absolute measuring tool that can be used by government, manufacturers, or consumers to evaluate not only their environmental performance but also both social and economic performance [16].

The guidelines for the implementation of SD were also indicated by the Global Reporting Initiative (GRI), which is an international model for reporting responsible business and sustainable development for companies [19]. Indicators in GRI are divided into six aspects influencing sustainable development in manufacturing companies: energy and material usage (EM), emissions into the natural environment $(\mathrm{NE})$, economic performance $(\mathrm{EP})$, products $(\mathrm{P})$, workers $(\mathrm{W})$, and community development and social justice (CS) [20].

Shibin [21] indicated that sustainable development in the production phase should be analysed in three areas: (1) production processes, (2) production durability, (3) product development. Therefore, the first element in our approach to assessing sustainability in the development of a manufacturing company was defining the SD objectives in three areas-A1: production process, A2: production durability, A3: development product. Analysis of the source literature [21-26] allowed the goals affecting the implementation of SD in manufacturing companies to be defined:

1. A1: production processes: $\mathrm{O}_{\mathrm{pp}} 1$-reduced energy consumption; $\mathrm{O}_{\mathrm{pp}} 2$-reduced environmental pollution; $\mathrm{O}_{\mathrm{pp}} 3$-improved quality of the process; $\mathrm{O}_{\mathrm{pp}} 4$-reduced material intensity in the manufacturing process; $\mathrm{O}_{\mathrm{pp}} 5$-economic production; $\mathrm{O}_{\mathrm{pp}} 6$-increasing innovation; $\mathrm{O}_{\mathrm{pp}} 7$-recycling, reduction of the amount of waste produced.

2. A2: production durability: $\mathrm{O}_{\mathrm{D}} 1$-high quality of products; $\mathrm{O}_{\mathrm{D}} 2$-prevention of downtime; $\mathrm{O}_{\mathrm{D}} 3$-closed loop materials; $\mathrm{O}_{\mathrm{D}} 4$-improved product reliability, product life; $\mathrm{O}_{\mathrm{D}}$ 5-repairability/service.

3. A3: development product: $\mathrm{O}_{\mathrm{V}} 1$-customer and employee satisfaction; $\mathrm{O}_{\mathrm{V}} 2-$ safety in the workplace, decent working conditions; $\mathrm{O}_{\mathrm{V}} 3$ - decent working conditions, safety in the workplace; $\mathrm{O}_{\mathrm{V}} 4$ - care regarding organisation, brand image; $\mathrm{O}_{\mathrm{V}} 5-$ manufacture of safe foods; $\mathrm{O}_{\mathrm{V}} 6$-increase in benefits to society without compromising future generations.

The selection of indicators to achieve the objectives of SD in a manufacturing company was made based on the $[4,15,20,27-30]$ in three areas: A1, A2, A3 (Table 2).

Table 2. Indicators of the achievement of the objectives of SD in a manufacturing company.

\begin{tabular}{|c|c|c|}
\hline \multicolumn{3}{|c|}{ A1: Production Process } \\
\hline SD Objectives & Mark & SD Indicators \\
\hline Reduced energy consumption & $\mathrm{O}_{\mathrm{pp}} 1$ & $\mathrm{~W}_{\mathrm{pp} 1}:$ Energy consumption \\
\hline \multirow{3}{*}{ Reduced environmental pollution } & \multirow{3}{*}{$\mathrm{O}_{\mathrm{pp}} 2$} & $\begin{array}{ll}\mathrm{W}_{\mathrm{pp} 2} \text { : Total air emissions during material extrusion: } \\
-\quad \text { to include greenhouse gases (GHGs) } \\
-\quad \text { ozone-depleting substances (ODS) } \\
-\quad \text { nitrogen oxides (NOx) } \\
-\quad \text { sulphur oxides (Sox) } \\
-\quad \text { volatile organic compounds (VOCs) } \\
-\quad \text { hazardous air pollutants (HAPs) and particulate matter (PM) }\end{array}$ \\
\hline & & \\
\hline & & $\begin{array}{l}\mathrm{W}_{\mathrm{pp} 3} \text { : Total air emissions at the suppliers: } \\
-\quad \text { to include greenhouse gases (GHGs) } \\
-\quad \text { ozone-depleting substances (ODS) } \\
-\quad \text { nitrogen oxides (NOx) } \\
-\quad \text { sulphur oxides (Sox) } \\
-\quad \text { volatile organic compounds (VOCs) } \\
-\quad \text { hazardous air pollutants (HAPs) and particulate matter (PM) }\end{array}$ \\
\hline
\end{tabular}


Table 2. Cont.

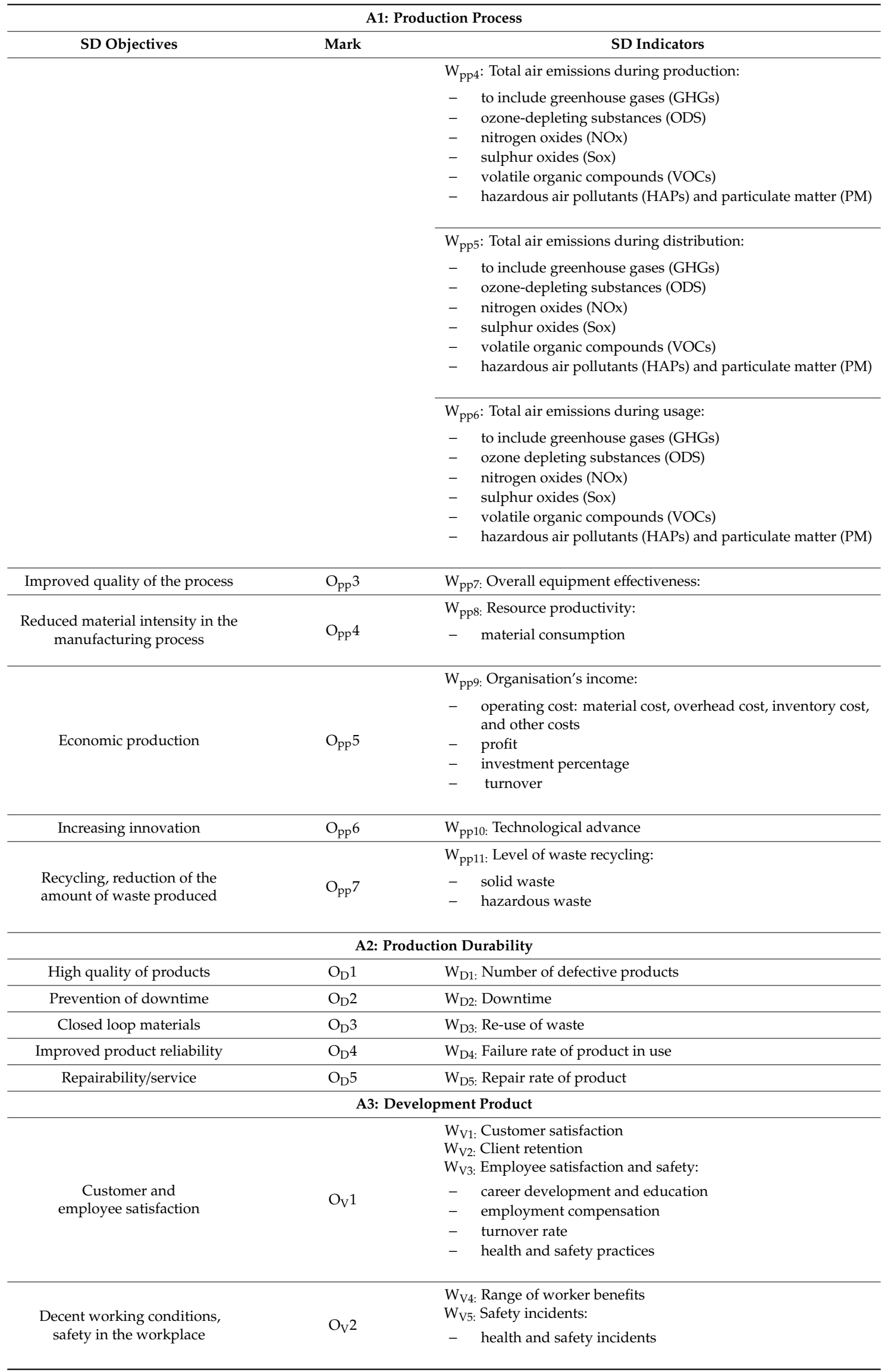


Table 2. Cont.

\begin{tabular}{|c|c|c|}
\hline \multicolumn{3}{|c|}{ A1: Production Process } \\
\hline SD Objectives & Mark & SD Indicators \\
\hline $\begin{array}{l}\text { Cost-effective manufacturing, } \\
\text { societally and creatively speaking }\end{array}$ & $\mathrm{O}_{\mathrm{V}} 3$ & $\begin{array}{l}\mathrm{W}_{\mathrm{V} 6:} \text { Cost of product, compared to similar products } \\
\mathrm{W}_{\mathrm{V} 7} \text { S Suppliers' price/Market price }\end{array}$ \\
\hline $\begin{array}{l}\text { Care regarding organisational, } \\
\text { brand image }\end{array}$ & $\mathrm{O}_{\mathrm{V}} 4$ & $\begin{array}{l}\mathrm{W}_{\mathrm{V8}} \text { : The prompt completion of orders } \\
\mathrm{W}_{\mathrm{V} 9:} \text { Number of complaints and returned products }\end{array}$ \\
\hline Manufacture of safe foods & $\mathrm{O}_{\mathrm{V}} 5$ & $\begin{array}{l}W_{V 10:} \text { Hours of safety training per employee } \\
W_{V 11:} \text { Hazardous chemicals used in production } \\
W_{V 12:} \text { Hazardous chemicals in products }\end{array}$ \\
\hline $\begin{array}{l}\text { Increase in benefits to society, } \\
\text { without compromising } \\
\text { future generations }\end{array}$ & $\mathrm{O}_{\mathrm{V}} 6$ & $\mathrm{~W}_{\mathrm{V} 13:}$ Risk management related to the climate \\
\hline
\end{tabular}

However, all existing indicators of the achievement of the objectives of SD could not simply be applied to every sector [26]. In our approach, indicators reaching specific SD goals were defined adequately vis-à-vis the specifics of the manufacturing enterprise of the SME sector. This was established on the basis of the results of empirical research into metal industry manufacturing companies in western Poland (Europe) at the end of 2019.

\subsection{The Use of the AHP Method in SD Measures within a Manufacturing Company}

In order to determine the key indicators to reach specific SD goals in a manufacturing company, the Analytic Hierarchy Process (AHP) method was used, which is the third element of our approach. The AHP method is one of the multi-criteria discrete methods [17]. The AHP method helps to solve problems related to making the best choice when the selection of a variant is based on the subjective preferences of a researched group or person [29]. The AHP is a systematic decision-making method that includes both qualitative and quantitative techniques [30]. The use of the AHP method facilitates the decision-making process in cases where the selection of chosen criteria is not necessarily measurable, as is the case with social, environmental, and economic criteria. The application of the AHP method consists in deconstructing a given issue into its basic components, which then undergo pairwise comparison, thus facilitating the choice of the best solution from the alternatives selected. Finding the best solution by applying the AHP method consists in constructing a pairwise comparison matrix. The matrix takes the dimensions of $\mathrm{N} \times \mathrm{N}$, where $\mathrm{N}$ stands for the number of components assigned to a given level. The characteristic feature of the matrix is that [31] terms that are placed on the diagonal of the matrix take the value of $\mathrm{a}_{\mathrm{ii}}=1$, while values above the diagonal are the result of the comparison of the two criteria $\left(\mathrm{a}_{\mathrm{ij}}\right)$, and terms placed below the diagonal constitute the reverse of this comparison $\left(\mathrm{a}_{\mathrm{ji}} \mathrm{i}\right)$. The procedure for determining local weights is then launched in the following manner: (1) determine the sum of the evaluation values in each column; (2) divide each of the evaluations obtained by the number of components. The sum of the weights obtained should equal 1.0. On the basis of the weights obtained, the materiality rankings of the selected alternative are indicated. In order to check the accuracy of the calculations, having obtained the values of the weights, one needs to measure consistency in the comparisons, which is representative of the proportionality of the preferences. For this purpose, a consistency index (CI) is constructed, followed by a consistency ratio (CR). It is assumed that comparison is consistent where $C R \leq 10 \%$ (for $n \leq 5$ ). If the consistency ratio is not accepted, the whole-or part-of the comparison needs to be repeated. Source literature (Table 3) indicated a number of advantages stemming from the application of the AHP methods in decision-making processes [32]: ability to capture both quantitative and qualitative attributes in a simple manner, popularity, simplicity in implementing and interpreting, capability in handling sparse or poor quality data, consistency test to ensure judgements quality. 
Table 3. Application of AHP methods in the decision support process.

\begin{tabular}{|c|c|c|c|c|c|}
\hline Area of Application & Methods Used & IT Systems Support & SD & Scope & Source \\
\hline Quality management & AHP; Six-Sigma & NO & $\mathrm{NO}$ & $\begin{array}{l}\text { Manufacturing } \\
\text { company }\end{array}$ & [33] \\
\hline $\begin{array}{l}\text { To improve } \\
\text { reliability of product }\end{array}$ & $\begin{array}{l}\text { AHP; FMEA (Failure } \\
\text { Mode and Effects } \\
\text { Analysis); AFD } \\
\text { (Anticipatory Failure } \\
\text { Determination) }\end{array}$ & $\mathrm{NO}$ & $\mathrm{NO}$ & $\begin{array}{l}\text { Automotive; } \\
\text { Manufacturing } \\
\text { company }\end{array}$ & [33] \\
\hline $\begin{array}{l}\text { Selection of an } \\
\text { underground metal } \\
\text { mining method }\end{array}$ & $\begin{array}{c}\text { AHP; } \\
\text { F-AHP(Fuzzy-AHP) }\end{array}$ & NO & $\mathrm{NO}$ & Extraction & [34] \\
\hline $\begin{array}{l}\text { Supply Chain } \\
\text { Management; green } \\
\text { supplier selection }\end{array}$ & $\begin{array}{l}\text { Fuzzy TOPSIS } \\
\text { (Technique for Order } \\
\text { Preference by Similarity } \\
\text { to Ideal Solution); AHP }\end{array}$ & NO & YES & - & [35] \\
\hline $\begin{array}{l}\text { Prioritisation of key } \\
\text { performance } \\
\text { indicators }\end{array}$ & AHP; SMARTER & $\mathrm{NO}$ & $\mathrm{NO}$ & $\begin{array}{l}\text { Manufacturing } \\
\text { company }\end{array}$ & [36] \\
\hline
\end{tabular}

F-AHP is an extension of AHP to the fuzzy theory. The main concept of F-AHP remains to develop a preferential weighting for each alternative decision, where preferences are specified using natural language or numerical values in order to determine the importance of each attribute [37]. The AHP method was used for the final selection of indicators, because the management board of the company examined always assesses their validity.

\subsection{SD-ERP Index Value Base, Using the ERP System}

Next, we know that the data and information necessary to obtain the indicator values assigned to a given goal can be obtained from the ERP system implemented in the company. The ERP system can be defined as an "IT based computer platform that allows integration of various business processes of an organisation in order to increase efficiency, and thus profits, using a single database" [34]. One task that could be undertaken by an ERP system might be to support activities that monitor the level of sustainable development in a manufacturing enterprise. Thus, our fourth element is the SD-ERP values base, which is obtained a result of the use of the ERP system. Table 4 presents the functionalities of the ERP system by which it is possible to obtain SD indicator values. Our approach assumes that manufacturing SMEs have and use the ERP system, but the need for its expansion is related to the need to implement activities in the company that will lead to 'Sustainable Manufacturer' status. Sustainable Manufacturing (SM) is an integration of the economic, environmental, and social approaches to the manufacturing enterprise [35]. Research aimed at providing solutions towards more sustainable development in manufacturing is of the utmost importance today and more urgent than ever [36].

Table 4. SD-ERP index value base, using the ERP system.

\begin{tabular}{|c|c|c|c|}
\hline F-Functionality & $\begin{array}{c}\text { Production Processes } \\
\left\{\mathbf{I}_{\mathrm{pp} 1}, \mathbf{I}_{\mathrm{pp}} \ldots \ldots, \mathbf{I}_{\mathrm{pp} 11}\right\}\end{array}$ & $\begin{array}{c}\text { Production Durability } \\
\quad\left\{\mathbf{I}_{\mathrm{D} 1}, \mathbf{I}_{\mathrm{D}} \ldots \ldots, \mathbf{I}_{\mathrm{D} 6}\right\}\end{array}$ & $\begin{array}{l}\text { Product Development } \\
\quad\left\{\mathbf{I}_{\mathrm{V} 1}, \mathbf{I}_{\mathrm{V}} \ldots \ldots, \mathbf{I}_{\mathrm{V} 11}\right\}\end{array}$ \\
\hline F1: Production & $\mathrm{x}$ & $\mathrm{x}$ & $\mathrm{x}$ \\
\hline F2: Trade and distribution & & $\mathrm{x}$ & $\mathrm{x}$ \\
\hline $\begin{array}{l}\text { F3: Customer relationship } \\
\text { management }\end{array}$ & & & $\mathrm{x}$ \\
\hline F4: Service and repairs & & $\mathrm{x}$ & \\
\hline F5: Human resources and payroll & $\mathrm{x}$ & & $\mathrm{x}$ \\
\hline F6: Warehouse & $x$ & & $x$ \\
\hline
\end{tabular}


In order to receive the SD values of the sustainability of the A1: production process, A2: production durability, and A3: development product, the data currently available in the ERP are linked to our Sustainable Development Card.

\subsection{The Sustainable Development Card}

Recommendations for improving the sustainability level in the company analysed are possible based on a comparison of the key SD values, which have been identified as the main indicators using the AHP method with the reference values for the SD. The reference SD values for a given class of enterprises in a given area should be determined by experts or based on the statistical data of a given country. Having researched the source literature and measures applied in manufacturing companies, we formed the SDC for a manufacturing company using an ERP system. This consisted of the following components: (1) SD objectives and goals in the enterprise, (2) the functionality of the ERP system, (3) the AHP method, (4) the value database of SD-ERP indicators. Our proposed approach to assessing sustainability, integrated with the ERP system in the development of a manufacturing company, is presented in the Table 5 .

Table 5. The Sustainable Development Card.

\begin{tabular}{|c|c|c|c|c|c|}
\hline $\begin{array}{l}\text { Element 1a: } \\
\text { SD Objectives }\end{array}$ & $\begin{array}{l}\text { Element 1b: } \\
\text { SD Indicators }\end{array}$ & $\begin{array}{l}\text { Element 2: } \\
\text { Functionality of the } \\
\text { ERP System }\end{array}$ & $\begin{array}{c}\text { Elements } 3 \text { and 4: } \\
\text { SD Values (ERP or Manually) } \\
\text { According to Results Obtained } \\
\text { from Using AHP Method }\end{array}$ & $\begin{array}{l}\text { SD Reference } \\
\text { Values }\end{array}$ & $\begin{array}{l}\text { Recommended } \\
\text { Action }\end{array}$ \\
\hline \multicolumn{6}{|c|}{ A1: production processes } \\
\hline $\mathrm{O}_{\mathrm{pp}} 1$ & $\mathrm{I}_{\mathrm{pp}} 1$ & F1, F5, F6 & $\ldots$ & $\ldots$ & $\ldots$ \\
\hline \multicolumn{6}{|c|}{$\ldots$} \\
\hline \multicolumn{6}{|c|}{ A2: production durability } \\
\hline $\mathrm{O}_{\mathrm{D}} 1$ & $\mathrm{I}_{\mathrm{D}} 1$ & F1, F2, F4 & $\ldots$ & $\ldots$ & $\ldots$ \\
\hline \multicolumn{6}{|c|}{$\ldots$} \\
\hline \multicolumn{6}{|c|}{ A3: development product } \\
\hline $\mathrm{O}_{\mathrm{V}} 1$ & $\mathrm{I}_{\mathrm{V}} 1$ & F1-F3, F5, F6 & $\ldots$ & $\ldots$ & $\ldots$ \\
\hline
\end{tabular}

\subsection{A Polish Manufacturing Company}

The approach proposed was implemented in a Polish manufacturing company specialising in steel processing. The company researched had 19 employees; these included 16 production workers. The company ran a two-shift work arrangement with the total working hours per shift being $8 \mathrm{~h}$. The study covered data relating to the completion of an order for 3000 pieces of $5 \mathrm{~mm}$ thick steel sheeting elements. The company analysed had the following machine inventory: Haas SL-20 LHE lathe (Manufacturer: Hass Automation, Inc., Oxnard, CA, USA), Takisawa TMM-250M1 lathe with driven tools (Manufacturer: Takisawa Machine Tool Co., Ltd., Okayama, Japan), Hermle C600U 5-axis machining centre (Manufacturer: Hermle, Gosheim, Germany), HARTFORD PRO 800 3-axis machining centre (Manufacturer: HARTFORD, Taichung City, Taiwan), Feeler FV 600 SE 3-axis machining centre (Manufacturer: Feeler, Taipei City, Taiwan), Industrial gate plotter Kimla BPF 2131 (Manufacturer: Kimla, Częstochowa, Poland), Trumpf TruLaser 3530 laser (Manufacturer: Trumpf, Ditzingen, Germany), Bomar Ergonomic bandsaw (Manufacturer: BOMAR, Kraków, Poland), Altendorf F45 dimension saw (Manufacturer: Altendorf, Minden, Germany), ESAB TIG 2200i welder (Manufacturer: ESAB, Gothenburg, Sweden), ESAB TIG 3001i welder (Manufacturer: ESAB, Gothenburg, Sweden), ESAB Warrior 400i CC/CV welder with Feed 304w feeder (Manufacturer: ESAB, Gothenburg, Sweden); the enterprise researched also had its own fleet.

\section{Research Results-The Evidence from the Polish Manufacturing Company}

The first element of our SDC (Table 2) was applied to the manufacturing enterprise we researched. The following SD indicator values were manually received (Table 6). 
Table 6. The base of SD indicator values in the company.

\begin{tabular}{ccc}
\hline SD Indicator & SD Value & Data Source \\
\hline & A1: Production process & \\
\hline $\mathrm{I}_{\mathrm{pp} 1}{ }^{*}$ & $26,141 \mathrm{kWh}$ & Manually \\
\hline & A2: Production durability \\
\hline $\mathrm{I}_{\mathrm{D} 1}$ & $14 / 3000$ piece & Manually \\
\hline & $\mathrm{A} 3:$ Development product & Manually \\
\hline $\mathrm{I}_{\mathrm{v} 1}$ & $92 \%$ &
\end{tabular}

Next, the AHP method was used for each of three SD areas in the manufacturing company. Experts from the company under analysis were selected to apply the AHP methods. The expert qualification process focussed on their experience, their involvement, and their knowledge of the use of manufacturing processes. Both a manager and a foreman in the manufacturing company were selected. In the process of selecting the experts, their knowledge and experience regarding the enterprise under discussion were mainly taken into account. When selecting criteria in the process of selecting experts, the specificity of the work performed was also taken into account. The company's management board appointed two employees because they had expert knowledge that was useful in the research conducted. Experts from other production companies were not appointed in the study, due to the lack of consent for cooperation of similar specificity by the production companies. The experts were then asked to assess the significance of indicators in three accepted areas: A1: production processes, A2: production durability, A3: development product.

This study adapted a scale of importance, based on which the pairwise comparison matrix was carried out. In the comparison process, Saaty's Fundamental Scale was adopted: 1-equal importance, no advantage of one variant over the other; 3 -weak dominance, moderate advantage of variant A over variant B; 5 -strong dominance, significant or strong advantage of variant $A$ over variant $B$; 7-demonstrable dominance, very strong advantage of variant $A$ over variant $B$; 9 -total dominance, extreme advantage of variant A over variant $B ; 2,4,6$, 8 -intermediate values; reciprocal scale: if activity $i$ has one of the above numbers in comparison to $j$-the inverse of $j$ is obtained.

The application of the AHP method was in MS Excel, and A1: production processes is presented in Table 7 as an example. The calculations for A2: production durability and A3: development product were performed in the same way.

Table 7. Pairwise comparison matrix in A1: production processes.

\begin{tabular}{ccccccccccccc}
\hline $\mathbf{I}$ & $\mathbf{I}_{\mathbf{1}}$ & $\mathbf{I}_{\mathbf{2}}$ & $\mathbf{I}_{\mathbf{3}}$ & $\mathbf{I}_{\mathbf{4}}$ & $\mathbf{I}_{\mathbf{5}}$ & $\mathbf{I}_{\mathbf{6}}$ & $\mathbf{I}_{\mathbf{7}}$ & $\mathbf{I}_{\mathbf{8}}$ & $\mathbf{I}_{\mathbf{9}}$ & $\mathbf{I}_{\mathbf{1 0}}$ & $\mathbf{I}_{\mathbf{1 1}}$ & $\mathbf{S U M}$ \\
\hline $\mathrm{I}_{\mathrm{pp} 1}$ & 1.00 & 1.00 & 1.00 & 1.00 & 1.00 & 1.00 & 1.00 & 2.00 & 0.50 & 2.00 & 1.00 & 12.5 \\
\hline $\mathrm{I}_{\mathrm{pp} 2}$ & 1.00 & 1.00 & 1.00 & 1.00 & 1.00 & 1.00 & 0.50 & 0.50 & 0.50 & 2.00 & 1.00 & 10.5 \\
\hline $\mathrm{I}_{\mathrm{pp} 3}$ & 1.00 & 1.00 & 1.00 & 1.00 & 1.00 & 1.00 & 0.50 & 0.50 & 0.50 & 1.00 & 0.50 & 9.0 \\
\hline $\mathrm{I}_{\mathrm{pp} 4}$ & 1.00 & 1.00 & 1.00 & 1.00 & 1.00 & 1.00 & 0.50 & 0.50 & 2.00 & 1.00 & 0.50 & 10.5 \\
\hline $\mathrm{I}_{\mathrm{pp} 5}$ & 1.00 & 1.00 & 1.00 & 1.00 & 1.00 & 1.00 & 0.50 & 2.00 & 2.00 & 1.00 & 0.50 & 12.0 \\
\hline $\mathrm{I}_{\mathrm{pp} 6}$ & 1.00 & 1.00 & 1.00 & 1.00 & 1.00 & 1.00 & 0.50 & 0.50 & 0.50 & 1.00 & 2.00 & 10.5 \\
\hline $\mathrm{I}_{\mathrm{pp} 7}$ & 1.00 & 2.00 & 2.00 & 2.00 & 2.00 & 2.00 & 1.00 & 2.00 & 1.00 & 2.00 & 1.00 & 18.0 \\
\hline $\mathrm{I}_{\mathrm{pp} 8}$ & 0.50 & 2.00 & 2.00 & 2.00 & 0.50 & 2.00 & 0.50 & 1.00 & 1.00 & 2.00 & 1.00 & 14.5 \\
\hline $\mathrm{I}_{\mathrm{pp} 9}$ & 2.00 & 2.00 & 2.00 & 2.00 & 0.50 & 2.00 & 1.00 & 1.00 & 1.00 & 3.00 & 2.00 & 18.5 \\
\hline $\mathrm{I}_{\mathrm{pp} 10}$ & 0.50 & 0.50 & 1.00 & 1.00 & 1.00 & 1.00 & 0.50 & 0.50 & 0.33 & 1.00 & 0.50 & 7.8 \\
\hline $\mathrm{I}_{\mathrm{pp} 11}$ & 1.00 & 1.00 & 2.00 & 2.00 & 2.00 & 2.00 & 1.00 & 1.00 & 0.50 & 2.00 & 1.00 & 15.5 \\
\hline $\mathrm{SUM} \mathrm{A}$ & 11 & 13.5 & 15 & 15 & 12 & 15 & 7.5 & 11.5 & 9.8 & 18 & 11 & 139.9 \\
\hline
\end{tabular}


Weights were calculated for individual variants, and the results are presented in Tables 8 and 9.

Table 8. Matrix of pairwise comparisons-determination of weights for individual variants in A1: production processes.

\begin{tabular}{ccccccccccccc}
\hline $\mathbf{I}$ & $\mathbf{I}_{\mathbf{1}}$ & $\mathbf{I}_{\mathbf{2}}$ & $\mathbf{I}_{\mathbf{3}}$ & $\mathbf{I}_{\mathbf{4}}$ & $\mathbf{I}_{\mathbf{5}}$ & $\mathbf{I}_{\mathbf{6}}$ & $\mathbf{I}_{\mathbf{7}}$ & $\mathbf{I}_{\mathbf{8}}$ & $\mathbf{I}_{\mathbf{9}}$ & $\mathbf{I}_{\mathbf{1 0}}$ & $\mathbf{I}_{\mathbf{1 1}}$ & SUM \\
\hline $\mathrm{I}_{\mathrm{pp} 1}$ & 0.09 & 0.07 & 0.07 & 0.07 & 0.08 & 0.07 & 0.13 & 0.17 & 0.05 & 0.11 & 0.09 & 1.01 \\
\hline $\mathrm{I}_{\mathrm{pp} 2}$ & 0.09 & 0.07 & 0.07 & 0.07 & 0.08 & 0.07 & 0.07 & 0.04 & 0.05 & 0.11 & 0.09 & 0.81 \\
\hline $\mathrm{I}_{\mathrm{pp} 3}$ & 0.09 & 0.07 & 0.07 & 0.07 & 0.08 & 0.07 & 0.07 & 0.04 & 0.05 & 0.06 & 0.05 & 0.71 \\
\hline $\mathrm{I}_{\mathrm{pp} 4}$ & 0.09 & 0.07 & 0.07 & 0.07 & 0.08 & 0.07 & 0.07 & 0.04 & 0.20 & 0.06 & 0.05 & 0.86 \\
\hline $\mathrm{I}_{\mathrm{pp} 5}$ & 0.09 & 0.07 & 0.07 & 0.07 & 0.08 & 0.07 & 0.07 & 0.17 & 0.20 & 0.06 & 0.05 & 0.99 \\
\hline $\mathrm{I}_{\mathrm{pp} 6}$ & 0.09 & 0.07 & 0.07 & 0.07 & 0.08 & 0.07 & 0.07 & 0.04 & 0.05 & 0.06 & 0.18 & 0.85 \\
\hline $\mathrm{I}_{\mathrm{pp} 7}$ & 0.09 & 0.15 & 0.13 & 0.13 & 0.17 & 0.13 & 0.13 & 0.17 & 0.10 & 0.11 & 0.09 & 1.42 \\
\hline $\mathrm{I}_{\mathrm{pp} 8}$ & 0.05 & 0.15 & 0.13 & 0.13 & 0.04 & 0.13 & 0.07 & 0.09 & 0.10 & 0.11 & 0.09 & 1.09 \\
\hline $\mathrm{I}_{\mathrm{pp} 9}$ & 0.18 & 0.15 & 0.13 & 0.13 & 0.04 & 0.13 & 0.13 & 0.09 & 0.10 & 0.17 & 0.18 & 1.44 \\
\hline $\mathrm{I}_{\mathrm{pp} 10}$ & 0.05 & 0.04 & 0.07 & 0.07 & 0.08 & 0.07 & 0.07 & 0.04 & 0.03 & 0.06 & 0.05 & 0.61 \\
\hline $\mathrm{I}_{\mathrm{pp} 11}$ & 0.09 & 0.07 & 0.13 & 0.13 & 0.17 & 0.13 & 0.13 & 0.09 & 0.05 & 0.11 & 0.09 & 1.20 \\
\hline & & & & & & & & & & & & \\
\hline
\end{tabular}

Table 9. Ranking of variants adopted in A1: production processes.

\begin{tabular}{ccc}
\hline Indicator & Weight & Priority \\
\hline $\mathrm{I}_{\mathrm{pp} 1}$ & 0.09 & 4 \\
\hline $\mathrm{I}_{\mathrm{pp} 2}$ & 0.07 & 7 \\
\hline $\mathrm{I}_{\mathrm{pp} 3}$ & 0.06 & 6 \\
\hline $\mathrm{I}_{\mathrm{pp} 4}$ & 0.08 & 5 \\
\hline $\mathrm{I}_{\mathrm{pp} 5}$ & 0.09 & 4 \\
\hline $\mathrm{I}_{\mathrm{pp} 6}$ & 0.08 & 5 \\
\hline $\mathrm{I}_{\mathrm{pp} 7}$ & 0.13 & 1 \\
\hline $\mathrm{I}_{\mathrm{pp} 8}$ & 0.10 & 3 \\
\hline $\mathrm{I}_{\mathrm{pp} 9}$ & 0.13 & 1 \\
\hline $\mathrm{I}_{\mathrm{pp} 10}$ & 0.06 & 6 \\
\hline $\mathrm{I}_{\mathrm{pp} 11}$ & 0.11 & 2 \\
\hline $\mathrm{SUM} \mathrm{A}$ & 1.000 & - \\
\hline
\end{tabular}

Next, the inconsistency index was determined (Table 10). 
Table 10. Determining the inconsistency index in A1: production processes.

\begin{tabular}{cccc}
\hline Indicator & Sum of Rating & Weight & $\chi_{\max }$ \\
\hline $\mathrm{I}_{\mathrm{pp} 1}$ & 11 & 0.09 & 1.01 \\
\hline $\mathrm{I}_{\mathrm{pp} 2}$ & 13.5 & 0.07 & 1.0 \\
\hline $\mathrm{I}_{\mathrm{pp} 3}$ & 15 & 0.06 & 0.97 \\
\hline $\mathrm{I}_{\mathrm{pp} 4}$ & 15 & 0.08 & 1.18 \\
\hline $\mathrm{I}_{\mathrm{pp} 5}$ & 12 & 0.09 & 1.08 \\
\hline $\mathrm{I}_{\mathrm{pp} 6}$ & 15 & 0.08 & 1.15 \\
\hline $\mathrm{I}_{\mathrm{pp} 7}$ & 7.5 & 0.13 & 0.97 \\
\hline $\mathrm{I}_{\mathrm{pp} 8}$ & 11.5 & 0.10 & 1.14 \\
\hline $\mathrm{I}_{\mathrm{pp} 9}$ & 9.8 & 0.13 & 1.29 \\
\hline $\mathrm{I}_{\mathrm{pp} 10}$ & 18 & 0.06 & 1.00 \\
\hline $\mathrm{I}_{\mathrm{pp} 11}$ & 11 & 0.11 & 1.20 \\
\hline & $\mathrm{SUM}$ & & 11.99 \\
\hline
\end{tabular}

Consistency index: $C I=\frac{\operatorname{lmax}-n}{(n-1)}=\frac{11.99-11}{(11-1)}=0.1$,

where: $n$-dimension of comparison matrix $(n=11)$.

Consistency ratio: $C R=\frac{100 \% * C I}{R I}=\frac{100 \% * 0.1}{1.52}=6.58 \%$.

The resulting $C R \leq 10 \%$ indicated that comparison logic was maintained when comparing items. For area A2: production durability the following ranking of variants was determined (Table 11):

Table 11. Ranking of variants adopted in A2: production durability.

\begin{tabular}{ccc}
\hline Indicator & Weight & Priority \\
\hline $\mathrm{I}_{\mathrm{D} 1}$ & 0.10 & 4 \\
\hline $\mathrm{I}_{\mathrm{D} 2}$ & 0.18 & 3 \\
\hline $\mathrm{I}_{\mathrm{D} 3}$ & 0.22 & 2 \\
\hline $\mathrm{I}_{\mathrm{D} 4}$ & 0.25 & 1 \\
\hline $\mathrm{I}_{\mathrm{D} 5}$ & 0.16 & 4 \\
\hline $\mathrm{I}_{\mathrm{D} 6}$ & 0.10 & 5 \\
\hline $\mathrm{SUM}$ & 1.000 & - \\
\hline
\end{tabular}

Inconsistency index: sum: 6.12 ,

Consistency index: $C I=\frac{\operatorname{lmax}-n}{(n-1)}=\frac{6.12-6}{(6-1)}=0.02$,

where: $n$-dimension of comparison matrix $(n=6)$.

Consistency ratio: $C R=\frac{100 \% * C I}{R I}=\frac{100 \% * 0.02}{1.25}=1.6 \%$.

The resulting $C R \leq 10 \%$ indicated that the comparison logic was maintained when comparing items. For area A3: product development the following ranking of variants was determined (Table 12): 
Table 12. Ranking of variants adopted in A3: product development.

\begin{tabular}{ccc}
\hline Indicator & Weight & Priority \\
\hline $\mathrm{I}_{\mathrm{V} 1}$ & 0.06 & 6 \\
\hline $\mathrm{I}_{\mathrm{V} 2}$ & 0.06 & 6 \\
\hline $\mathrm{I}_{\mathrm{V} 3}$ & 0.10 & 2 \\
\hline $\mathrm{I}_{\mathrm{V} 4}$ & 0.07 & 5 \\
\hline $\mathrm{I}_{\mathrm{V} 5}$ & 0.11 & 1 \\
\hline $\mathrm{I}_{\mathrm{V} 6}$ & 0.07 & 5 \\
\hline $\mathrm{I}_{\mathrm{V} 7}$ & 0.04 & 8 \\
\hline $\mathrm{I}_{\mathrm{V} 8}$ & 0.05 & 7 \\
\hline $\mathrm{I}_{\mathrm{V} 9}$ & 0.06 & 6 \\
\hline $\mathrm{I}_{\mathrm{V} 10}$ & 0.09 & 3 \\
\hline $\mathrm{I}_{\mathrm{V} 11}$ & 0.10 & 2 \\
\hline $\mathrm{I}_{\mathrm{V} 12}$ & 0.10 & 2 \\
\hline $\mathrm{I}_{\mathrm{V} 13}$ & 0.08 & - \\
\hline $\mathrm{SU}$ M & 1.000 &
\end{tabular}

Inconsistency index: sum: 14.04,

Consistency index: $C I=\frac{l \max -n}{(n-1)}=\frac{14.04-13}{(13-1)}=0.09$,

where: $\mathrm{n}$-dimension of comparison matrix $(\mathrm{n}=13)$.

Consistency ratio: $C R=\frac{100 \% * C I}{R I}=\frac{100 \% * 0.09}{1.56}=5.77 \%$.

The resulting $C R \leq 10 \%$ indicated that comparison logic was maintained when comparing items.

By using the AHP method in our approach, it was possible to determine which SDs were the most important indicators for obtaining the status of Sustainable Manufacturer and-thanks to this-define the order of implementation vis-à-vis the actions needed for improving the sustainability levels of the company with regard to its specific business processes. In our case study, the most important indicators according to the first three priorities were assigned because the management board in the company assumed such conditions for further analysis. Based on the results, the most important SD indicators of sustainability in the development of a manufacturing company are:

- A1: production processes: $\mathrm{I}_{\mathrm{pp} 7}$ and $\mathrm{I}_{\mathrm{pp} 9} ; \mathrm{I}_{\mathrm{pp} 11}$ and $\mathrm{I}_{\mathrm{pp} 8} ;$

- A2: production durability: $\mathrm{I}_{\mathrm{D} 4} ; \mathrm{I}_{\mathrm{D} 3} ; \mathrm{I}_{\mathrm{D} 2}$;

- A3: product development: $\mathrm{I}_{\mathrm{V} 5} ; \mathrm{I}_{\mathrm{V} 3}$ and $\mathrm{I}_{\mathrm{V} 11}$ and $\mathrm{I}_{\mathrm{V} 12} ; \mathrm{I}_{\mathrm{V} 10}$.

In the fourth element, according to the results of our AHP analysis, an SD-ERP indicators value database was designed for the manufacturing enterprise researched. The values of the SD indicators were obtained with the help of the ERP system. The reference values for SD indicators were determined as a direct result of interviews conducted with managers of manufacturing companies in the western region of Poland. Thus, managers received the SDC; this was to be used in tandem with the ERP system (Table 13).

Our approach was that the SDC and the use of AHP are universal and can be used for various companies. However, the importance of SD indicators was determined by the opinions of experts from a given company; it was, therefore, possible to determine those that were the most important SD indicators for the analysed company only.

Thanks to the implementation of the card in the company analysed, it was possible to define the necessary corrective actions that the company must take to increase its SD level. In area A1: production processes, defining the actions for improving the sustainable level of the company was also required. Knowing that the main technological processes in the steel processing company analysed are 
energy-consuming and cause high $\mathrm{CO}_{2}$ emissions into the atmosphere, the following activities are proposed, in order to improve the quality of the process and economic production:

- The introduction of controls into the parameters for steel processing in order to shorten these processes, reduce energy consumption, and reduce the number of shortages;

- Implementation of servicing and repair planning, maintenance of machinery and equipment, regular screening of machinery and equipment for efficiency.

In area A2: production durability, implementation of servicing and repair planning is also required. For A3, no actions for the improvement of the sustainable level of the company are required.

Table 13. Matrix of the most important SD indicators-the Sustainable Development Card.

\begin{tabular}{|c|c|c|c|c|c|}
\hline $\begin{array}{c}\text { Element 1a: } \\
\text { SD Objectives }\end{array}$ & $\begin{array}{l}\text { Element 1b: } \\
\text { SD Indicators }\end{array}$ & $\begin{array}{c}\text { Element 2: } \\
\text { Functionality of } \\
\text { the ERP System }\end{array}$ & $\begin{array}{c}\text { Elements } 3 \text { and } 4: \\
\text { SD Values (ERP or Manually) } \\
\text { According to Results of } \\
\text { Using AHP Method }\end{array}$ & $\begin{array}{l}\text { SD Reference } \\
\text { Values }\end{array}$ & $\begin{array}{c}\text { Recommended } \\
\text { Action }\end{array}$ \\
\hline \multicolumn{6}{|c|}{ A1: production processes } \\
\hline $\mathrm{O}_{\mathrm{pp}} 3$ & $\mathrm{I}_{\mathrm{pp} 7}$ & $\mathrm{~F} 1$ & $55.39 \%$ & $85 \%$ & $\begin{array}{l}\text { the introduction of } \\
\text { controls into the } \\
\text { parameters for } \\
\text { steel processing, } \\
\text { implementation of } \\
\text { servicing and } \\
\text { repair planning }\end{array}$ \\
\hline $\mathrm{O}_{\mathrm{pp}} 5$ & $\mathrm{I}_{\mathrm{pp} 9}$ & F2 & - & $<5 \%$ & - \\
\hline $\mathrm{O}_{\mathrm{pp} 7}$ & $\mathrm{I}_{\mathrm{pp} 11}$ & F1 & $52 \%$ & $50 \%$ & no actions \\
\hline $\mathrm{O}_{\mathrm{pp} 4}$ & $\mathrm{I}_{\mathrm{pp} 8}$ & F1, F5 & $94 \%$ & $95 \%$ & no actions \\
\hline \multicolumn{6}{|c|}{ A2: production durability } \\
\hline $\mathrm{O}_{\mathrm{D} 3}$ & $\mathrm{I}_{\mathrm{D} 4}$ & F1, F3, F4, F5 & - & $100 \%$ & - \\
\hline $\mathrm{O}_{\mathrm{D} 2}$ & $\mathrm{I}_{\mathrm{D} 3}$ & $\mathrm{~F} 1$ & - & $50 \%$ & - \\
\hline $\mathrm{O}_{\mathrm{D} 1}$ & $\mathrm{I}_{\mathrm{D} 2}$ & $\mathrm{~F} 1, \mathrm{~F} 4$ & $20 \%$ & $5 \%$ & $\begin{array}{l}\text { implementation of } \\
\text { servicing and } \\
\text { repair planning }\end{array}$ \\
\hline \multicolumn{6}{|c|}{ A3: product development } \\
\hline $\mathrm{O}_{\mathrm{V}} 2$ & $\mathrm{I}_{\mathrm{V} 5}$ & F5 & 0 incident & 0 incident & no actions \\
\hline $\mathrm{O}_{\mathrm{V} 1}$ & $\begin{array}{c}\mathrm{I}_{\mathrm{V} 3} \\
\text { (the last six } \\
\text { months were } \\
\text { adopted) }\end{array}$ & F3, F5 & - & $95 \%$ & - \\
\hline $\mathrm{O}_{\mathrm{V} 5}$ & $\mathrm{I}_{\mathrm{V} 11}$ & F1 & $0 \%$ & $0 \%$ & no actions \\
\hline $\mathrm{O}_{\mathrm{V} 5}$ & $\mathrm{I}_{\mathrm{V} 12}$ & $\mathrm{~F} 1$ & $0 \%$ & $0 \%$ & no actions \\
\hline $\mathrm{O}_{\mathrm{V} 5}$ & $\mathrm{I}_{\mathrm{V} 10}$ & F3, F5 & - & $<20 \%$ & - \\
\hline
\end{tabular}

We received the results of the assessment of sustainability, the card integrated with the ERP system (Table 13), which expressed the validity of SD and at the same time compared it with the obtained reference values of the SD. Moreover, the indicators and their weights were developed with the application of the AHP method, whose universality and practicality allow data to be easily modified and also extend the model with new criteria.

The proposed solution enables managers to control activities undertaken in real time, reduce costs - both in HR and in manufacturing - as well as save resources and energy and implement an environmental policy. The solution proposed also constitutes a database for further actions. The model, through actual control of SD indicator values, allows the changes implemented in the modified environment to be verified.

This solution allows experts to accurately assess the effects of the actions taken and gather feedback. We propose that this SDC be added to the organisation's strategy because it allows

- Evaluation of the SD practices in the organisation; 
- Verification of the company's strategy for SD values;

- The possibilities and expectations of the organisation to be determined, thereby adding SD goals to the company's goals and strategy;

- The selection of experts inside the organisation;

- Recommended actions to be adopted by making plans at the corporate level and implementing cohesive action at the functional level;

- Progress/values of the indicators to be monitored and controlled;

- Recommended actions to be verified.

\section{Discussion and Limitations}

Activities undertaken in the company within the three main defined areas in the field of SD, namely, production process, production durability, and product development, have an impact on environmental, societal, and economic issues. The integration of these areas within a company requires the development of new solutions for companies supporting monitoring of the level of SD. The research conducted and its application in this real case study show that the SDC we developed clearly indicates the values of SD components while at the same time indicating their reference values, thus allowing implementation of corrective measures in particular areas of the company's operations.

In our case study, selecting SD indicators for research was guided by their criteria and the frequency of their use, as presented in the extensive literature on the subject (Section 3.1). Because of the specificity of technological processes in the A1 area of enterprise analysed, actions were mainly proposed to improve the quality of the process in terms of the environment and to increase the economic efficiency of production. The corrective actions proposed are consistent with the strategy adopted by the company's management board. In the case study, it was then considered that the ERP system and MS Excel be used to make it possible to indicate the current level of the SD indicators adopted vis-à-vis the analysis. The use of IT systems in the first place replaces the error-prone, manual entering of data in favour of automatic calculations, while the integration of data from various sources facilitates calculations with high accuracy [38]. The advantage of using the ERP system in the studies here presented is the access to current and regular information on the production flow, order status, materials used, distribution and production time, etc., thus achieving the goals of SD. In this particular case, the ERP system was recently implemented in the production company examined, which excluded downloading data from a wider time horizon and downloading fully automated information on organisational and production processes.

The universality of the proposed approach and its adaptability to the specifics of a given company allow it to be employed in both small and medium enterprises, as well as larger manufacturing companies. The selection of indicators, appropriate for the company examined, is particularly important due to the reliability and practicality of applying the results obtained. The problem still remains, however, that "companies usually use inappropriate or poorly classified indicators or compare their own results to previous periods where different conditions once prevailed before organisations could achieve anything" [39]. Apparently, economic efficiencies and benefits have often been achieved at the expense of the environment [38], which poses a problem in establishing objective key indicators and actions.

Therefore, the use of our approach encourages a holistic overview of the enterprise's SD, thus contributing to the development of competitive advantage. Defining goals and indicators in this research was a difficult task because the SD issue is multi-faceted. Although the AHP method is commonly used by specialists to aid decision-making, the source literature also pointed out its limitations, e.g., conventional, rigid scope of assessment (using Saaty's scale); a number of comparable problems where a limited number of variants is recommended for a reliable result; the need for cooperation with external experts with no involvement in achieving company goals; assumption of full comparability of accepted criteria and assessment variants. Evaluation is driven by analysis, both of the literature and of expert opinion. 
The limitation of our approach is that, based on the data obtained in the assessment of the sustainability table integrated with the ERP system (Table 13), actions should be taken to improve the level of sustainable production; these actions must be formulated by the company's managers or external experts. Similarly, reference values of SD must be obtained from external data. However, the advantage of the proposed approach is that it is possible to automatically receive information as to which business process within the company should involve the proposal of activities related to sustainable production. In addition, integration of the proposed sustainability table with the ERP system guarantees real-time control of the assessment of the sustainability of production.

The involvement of top management and all employees is a key aspect in SD management in organisations [40]. Therefore, it seems necessary to implement SD in basic business processes, which, according to the British Standards Institution (BSI) (2003), will facilitate the improvement and preservation of five types of capital, including: natural, human, financial, social, and industrial capital [15]. Loorbach et al. [41] introduced a conceptual framework for this purpose that allows the implementation of business process management, enabling organisations to strive for sustainable development. It was found that transforming an organisation into a sustainable organisation requires a permanent process and structural changes in the culture of the organisation as well as technological, economic, and organisational changes.

\section{Conclusions}

The idea, as presented, is an innovative approach to using the ERP system when evaluating the effectiveness of SD. The issue of SD in manufacturing companies is of key importance on a global scale. The Sustainable Development Card, as designed with regard to ERP, ensures realistic agendas and goals and

- $\quad$ Sets objectives for implementing an ERP system;

- Develops an indicator matrix;

- Assigns weights to particular actions;

- Has options to control and modify.

The proposed approach allows SD to be assessed and enables the implementation process of SD strategy to be constantly monitored, while application of the card ensures increased efficiency for any SD activities conducted and the ability to control them. Because of the lack of tools supporting the assessment of sustainability linked to the ERP system for manufacturing companies from the SME sector, the model discussed is new in its approach; applying it will bridge the gap in this area. Applying SDC facilitates

- Integration with the development of a strategy,

- Integration with the ERP system implemented in a company,

- Continuous monitoring of the sustainability level in a company,

- Continuous assessment of the sustainability level in a company.

Further research areas include extending the proposed approach to include the use of a decision tree. In manufacturing, the use of decision trees is common in quality management, knowledge management, project management, and in the automotive industry in order to generate prediction models [42] among other areas. The source literature indicated that the decision tree method has been used in SD to sustain household gas consumption [43], to develop an ecological quality assessment system for soil, to plan sustainable construction [44], and as a CONTRA aggregation tool for the multi-criteria assessment of sustainability [45]. This work will attempt to use a decision tree to automatically monitor the progress of the implementation of SD objectives and indicators. Moreover, further work will require research into the construction of our SDC in the form of an information system adapted for integration with the ERP system. 
Author Contributions: Conceptualization, J.P.-M.; methodology, J.P.-M. and H.Ł.; software, J.P.-M. and H.Ł.; validation, J.P.-M.; formal analysis, J.P.-M. and H.Ł.; investigation, J.P.-M.; resources, J.P.-M. and H.Ł.; data curation, J.P.-M. and H.Ł.; writing - original draft preparation, J.P.-M. and H.Ł.; writing-review and editing, J.P.-M. and H.Ł.; visualization, J.P.-M. and H.Ł.; supervision, J.P.-M.; project administration, J.P.-M.; funding acquisition, J.P.-M. All authors have read and agreed to the published version of the manuscript.

Funding: This research was supported by program of the Polish Minister of Science and Higher Education under the name "Regional Initiative of Excellence" in 2019-2022, project no. 003/RID/2018/19, funding amount PLN $11,936,596.10$.

Conflicts of Interest: The authors declare no conflict of interest.

\section{References}

1. Zalewska, M. Sustainable consumption and production-inequalities in European Union countries. Soc. Inequal. Econ. Growth 2015, 42, 2.

2. Carter, C.R.; Easton, P.L. Sustainable supply chain management: Evolution and future directions. Int. J. Phys. Distrib. Logist. Manag. 2011, 41, 46-62. [CrossRef]

3. Dyllick, T.; Hockerts, K. Beyond the business case for corporate sustainability. Bus. Strat. Environ. 2002, 11, 130-141. [CrossRef]

4. Nagarajan, H.P.N.; Raman, A.S.; Haapala, K.R. A Sustainability Assessment Framework for Dynamic Cloud-based Distributed Manufacturing. Procedia CIRP 2018, 69, 136-141. [CrossRef]

5. Costa, C.J.; Aparicio, M.; Raposo, J. Determinants of the management learning performance in ERP context. Heliyon 2020, 6, e03689. [CrossRef]

6. Plich, L. Integrated Management Systems ERP/ERP II. Use in Business, Implementation; Difin: Warszawa, Poland, 2003. (In Polish)

7. Barbosa, M.; -Ayarza, J.A.C.; Ferreira, D.H.L. Sustainable Strategic Management (GES): Sustainability in small business. J. Clean. Prod. 2020, 258, 120880. [CrossRef]

8. Danish, M.S.S.; Elsayed, M.E.L.; Ahmadi, M.; Senjyu, T.; Karimy, H.; Zaheb, H. A strategic-integrated approach for sustainable energy deployment. Energy Rep. 2020, 6, 40-44. [CrossRef]

9. Shukla, G.P.; Adil, G.K. Exploring Sustainability Implications for Manufacturing Strategy Decision Areas-A New Model with a Case Study. Procedia Manuf. 2020, 43, 352-359. [CrossRef]

10. Witek-Craab, A. Sustainable strategic management and market effectiveness of enterprises. Procedia Soc. Behav. Sci. 2012, 58, 899-905. [CrossRef]

11. SDG. Available online: http://sdg.gov.pl/statistics_glob/12-5-1/ (accessed on 17 October 2019).

12. Aboabdo, S.; Aldhoiena, A.; Al-Amrib, H. Implementing Enterprise Resource Planning ERP System in a Large Construction Company in KSA. Procedia Comput. Sci. 2019, 164, 463-470. [CrossRef]

13. Elkington, J.; Emerson, J.; Beloe, S. The Value Palette: A Tool for Full Spectrum Strategy. Calif. Manag. Rev. 2006, 48, 6-28. [CrossRef]

14. Johansson, G.; Winroth, M. Introducing environmental concern in manufacturing strategies. Manag. Res. Rev. 2010, 33, 877-899. [CrossRef]

15. Chofreh, A.G.; Goni, F.A.; Klemeš, J.J. Sustainable enterprise resource planning systems implementation: A framework development. J. Clean. Prod. 2018, 198, 1345-1354. [CrossRef]

16. Hasan, M.; Ebrahim, Z.; Wan Mahmood, W.; Ab Rahman, M. Sustainable-ERP System: A Preliminary Study on Sustainability Indicators. J. Adv. Manuf. Technol. 2017, 11, 61-74.

17. Chofreh, A.G.; Goni, F.A.; Klemeš, J.J.; Malik, M.N.; Khan, H.H. Development of guidelines for the implementation of sustainable enterprise resource planning systems. J. Clean. Prod. 2020, 244, 118655. [CrossRef]

18. Pohludka, M.; Stverkova, H.; Ślusarczyk, B. Implementation and Unification of the ERP System in a Global Company as a Strategic Decision for Sustainable Entrepreneurship. Sustainability 2018, 10, 2916. [CrossRef]

19. GRI. 2016. Available online: https://www.globalreporting.org/standards (accessed on 1 October 2020).

20. Fan, C.; Carrell, J.D.; Zhang, H.-C. An investigation of indicators for measuring sustainable manufacturing. In Proceedings of the 2010 IEEE International Symposium on Sustainable Systems and Technology, Arlington, VA, USA, 17-19 May 2010; pp. 1-5.

21. Shibin, K.T. Enablers of Sustainable Manufacturing Overview, Framework and Further Research Directions. Syst. Approaches Strateg. Manag. 2016, 52-73. [CrossRef] 
22. Moldavska, A.; Welo, T. Development of Manufacturing Sustainability Assessment Using Systems Thinking. Sustainability 2015, 8, 5. [CrossRef]

23. Moldavska, A.; Welo, T. A Holistic approach to corporate sustainability assessment: Incorporating sustainable development goals into sustainable manufacturing performance evaluation. J. Manuf. Syst. 2019, 50, 53-68. [CrossRef]

24. Rajak, S.; Vinodh, S. Application of fuzzy logic for social sustainability performance evaluation: A case study of an Indian automotive component manufacturing organization. J. Clean. Prod. 2015, 108, 1184-1192. [CrossRef]

25. Singh, M.; Ohji, T.; Asthana, R. Green and Sustainable Manufacturing of Advanced Materials-Progress and Prospects. In Green and Sustainable Manufacturing of Advanced Material; Elsevier: Amsterdam, The Netherlands, 2016; pp. 3-10.

26. Waas, T.; Hugé, J.; Block, T.; Wright, T.T.; Benitezcapistros, F.F.; Verbruggen, A. Sustainability Assessment and Indicators: Tools in a Decision-Making Strategy for Sustainable Development. Sustainability 2014, 6, 5512-5534. [CrossRef]

27. Chang, A.-Y.; Cheng, Y.-T. Analysis model of the sustainability development of manufacturing small and medium- sized enterprises in Taiwan. J. Clean. Prod. 2019, 207, 458-473. [CrossRef]

28. Machado, C.G.; Despeisse, M.; Winroth, M.; Da Silva, E.H.D.R. Additive manufacturing from the sustainability perspective: Proposal for a self-assessment tool. Procedia CIRP 2019, 81, 482-487. [CrossRef]

29. Benmoussa, K.; Laaziri, M.; Khoulji, S.; Kerkeb, M.L.; El Yamami, A.; Benmoussa, K. AHP-based Approach for Evaluating Ergonomic Criteria. Procedia Manuf. 2019, 32, 856-863. [CrossRef]

30. Saaty, T.L. The Analytic Hierarchy and Analytic Network Processes for the Measurement of Intangible Criteria and for Decision-Making. In International Series in Operations Research E Management Science; Springer Nature: Cham, Switherland, 2006; Volume 78, pp. 345-405. [CrossRef]

31. Mzougui, I.; El Felsoufi, Z. Proposition of a modified FMEA to improve reliability of product. Procedia CIRP 2019, 84, 1003-1009. [CrossRef]

32. Balusa, B.C.; Gorai, A.K. Sensitivity analysis of fuzzy-analytic hierarchical process (FAHP) decision-making model in selection of underground metal mining method. J. Sustain. Min. 2019, 18, 8-17. [CrossRef]

33. Hamdan, S.; Cheaitou, A. Supplier selection and order allocation with green criteria: An MCDM and multi-objective optimization approach. Comput. Oper. Res. 2017, 81, 282-304. [CrossRef]

34. Negahban, S. Utilization of Enterprise Resource Planning Tools by Small to Medium Size Construction Organizations: A Decision-Making Model. Dissertation Submitted to the Faculty of the Graduate School of the University of Maryland University of Maryland, College Park. 2008. Available online: https: //drum.lib.umd.edu/bitstream/handle/1903/8087/umi-umd-5251.pdf?sequence=1\&isAllowed=y (accessed on 19 September 2020).

35. Malek, J.; Desai, T.N. Prioritization of sustainable manufacturing barriers using Best Worst Method. J. Clean. Prod. 2019, 226, 589-600. [CrossRef]

36. Stark, R.; Seliger, G.; Bonvoisin, J. Sustainable Manufacturing, Life Cycle Engineering and Management; Springer: Berlin, Germany, 2017.

37. Kusumawardani, C.A.; Agintiara, M. Application of Fuzzy AHP-TOPSIS Method for Decision Making in Human Resource Manager Selection Process. Procedia Comput. Sci. 2015, 72, 638-646. [CrossRef]

38. Hack, S.; Berg, C. The Potential of IT for Corporate Sustainability. Sustainability 2014, 6, 4163-4180. [CrossRef]

39. Milichovský, F. Financial Key Performance Indicators in Engineering Companies. Period. Polytech. Soc. Manag. Sci. 2015, 23, 60-67. [CrossRef]

40. Burke, S.; Gaughran, W. Developing a framework for sustainability management in engineering SMEs. Robot. Comput. Manuf. 2007, 23, 696-703. [CrossRef]

41. Loorbach, D. Transition Management for Sustainable Development: A Prescriptive, Complexity-Based Governance Framework. 2009. Available online: https://www.researchgate.net/profile/Derk_Loorbach/ publication/229815520_Transition_Management_for_Sustainable_Development_A_Prescriptive_

Complexity-Based_Governance_Framework/links/5a55d154aca272bb6962b565/Transition-Managementfor-Sustainable-Development-A-Prescriptive-Complexity-Based-Governance-Framework.pdf (accessed on 22 September 2020).

42. Ahmed, M.; Afzal, H.; Majeed, A.; Khan, B. A Survey of Evolution in Predictive Models and Impacting Factors in Customer Churn. Adv. Data Sci. Adapt. Anal. 2017, 9. [CrossRef] 
43. Namazkhan, M.; Albers, C.; Steg, L. A decision tree method for explaining household gas consumption: The role of building characteristics, socio-demographic variables, psychological factors and household behaviour. Renew. Sustain. Energy Rev. 2020, 119, 10954. [CrossRef]

44. Park, J.; Ki, D.; Kim, K.; Lee, S.J.; Kim, D.H.; Oh, K.J. Using decision tree to develop a soil ecological quality assessment system for planning sustainable construction. Expert Syst. Appl. 2011, 38, 5463-5470. [CrossRef]

45. Bockstaller, C.; Beauchet, S.; Manneville, V.; Amiaud, B.; Botreau, R. A tool to design fuzzy decision trees for sustainability assessment. Environ. Model. Softw. 2017, 97, 130-144. [CrossRef]

Publisher's Note: MDPI stays neutral with regard to jurisdictional claims in published maps and institutional affiliations.

(C) 2020 by the authors. Licensee MDPI, Basel, Switzerland. This article is an open access article distributed under the terms and conditions of the Creative Commons Attribution (CC BY) license (http://creativecommons.org/licenses/by/4.0/). 